\title{
PEMBERDAYAAN EKONOMI MASYARAKAT MELALUI KERAJINAN RAJUT DESA SUMBEREJO KECAMATAN TRUCUK KABUPATEN BOJONEGORO
}

\author{
1) M. Romadlon Habibullah, \\ Universitas Nahdhatul Ulama`Sunan Giri Bojonegoro \\ *Email: ${ }^{1)}$ romadlon@ sunan-giri.ac.id
}

\begin{abstract}
ABSTRAC
The university is part of the intellectual community in this country, which is expected to be able to contribute to the development of the nation and state. Community Service Activities $(P K M)$ are a form of education by providing empirical experience to Lecturers with students to live in the midst of society outside the campus, and directly teaching students how to identify populist social problems. Sumberejo Village is a village located in Trucuk District, Bojonegoro, East Java. The implementation of the Covid-19 Thematic PKM activity was carried out in Sumberejo Village because the PKM location was an area close to student homes. In accordance with the direction of the Institute for Research and Community Service (LPPM) at the University of Nahdlatul Ulama Sunan Giri Bojonegoro that the implementation of PKM is better in their respective villages to reduce mobility and transmission of COVID-19. PKM in Sumberejo Village Using a Community Based Research approach, by carrying out a community assistance process using the Asset Based Community Development (ABCD) method. The 2021 Thematic PKM activity at the Sunan Giri Bojonegoro University Nahdlatul Ulama in Sumberejo Village, Trucuk District can be carried out well. Activities can be accepted by the community and receive support from all levels of village officials and several elements who are always enthusiastic about ongoing activities. Work programs that are focused on community economic development during the pandemic. The activity is in the form of developing yarn knitting skills. Marketing assistance for community knitting products, namely on social media and marketplaces. Marketing and introducing knitting products in Sumberajo Village which was carried out after development assistance.
\end{abstract}

Keywords; Economic Empowerment, Knitting Craft

\begin{abstract}
Abstrak
Perguruan tinggi merupakan bagian dari masyarakat intelektual yang ada di negeri ini, diharapkan mampu memberi andil dalam pembangunan bangsa dan Negara. Kegiatan Pengabdian Kepada Masyarakan (PKM) adalah suatu bentuk pendidikan dengan cara memberikan pengalaman empiris kepada Dosen Bersama mahasiswa untuk hidup ditengah-tengah masyarakat di luar kampus, dan secara langsung megajarkan kepada mahasiswa cara identifikasi masalah-masalah sosial kerakyatan. Desa Sumberejo adalah desa yang terletak di Kecamatan Trucuk, Bojonegoro, Jawa Timur. Pelaksanaan kegiatan PKM Tematik Covid-19 dilaksanakan di Desa Sumberejo karena lokasi PKM merupakan daerah yang dekat dengan rumah mahasiswa. Sesuai arahan dari Lembaga Penelitian dan Pengabdian Masyarakat (LPPM) perguruan tinggi Universitas Nahdlatul Ulama Sunan Giri Bojonegoro bahwa pelaksanaan PKM lebih baik di desa masing-masing untuk mengurangi mobilitas dan penularan COVID-19. PKM di Desa Sumberejo Menggunakan pendekatan Community Based Research, dengan melakukan proses pendampingan masyarakat yaitu dengan menggunakan metode Asset Based Community Development (ABCD). Kegiatan PKM Tematik 2021 Universitas Nahdlatul Ulama Sunan Giri Bojonegoro di Desa Sumberejo Kecamatan Trucuk dapat terlaksana dengan baik. Kegiatan dapat diterima oleh
\end{abstract}


masyarakat dan mendapat dukungan oleh seluruh jajaran perangkat desa dan beberapa elemen yang senantiasa antusias dengan kegiatan yang berjalan.Program kerja yang difokuskan pada pengembangan ekonomi masyarakat di masa pandemi. Kegiatan tersebut berupa pengembangan ketrampilan merajut benang Pendampingan pemasaran hasil rajut masyasarakat yaitu di media sosial dan marketplace. Memasarkan dan mengenalkan produk rajut Desa Sumberajo yang dilaksanakan setelah adanya pendampingan Pengembangan.

Kata kunci; Pemberdayaan Ekonomi, Kerajinan Rajut

\section{PENDAHULUAN}

Perguruan tinggi merupakan bagian dari masyarakat intelektual yang ada di negeri ini, diharapkan mampu memberi andil dalam pembangunan bangsa dan Negara. Pembangunan disektor fisik yang terus malaju seiring dengan pesatnya kemajuan ilmu pengetahuan dan teknologi perlu diimbangi dengan kemajuan masyarakat pada aspek nonfisik. Sejauh ini kemajuan ilmu pengetahuan dan teknologi masih menyisakan ketertinggalan masyarakat pada aspek nonfisik. Dunia pendidikan, kesehatan masyarakat, dan kesejahteraan masih jauh menjadi problem klasik yang butuh penanganan serius.

Kegiatan Pengabdian Kepada Masyarakan (PKM) adalah suatu bentuk pendidikan dengan cara memberikan pengalaman empiris kepada Dosen Bersama mahasiswa untuk hidup ditengah-tengah masyarakat di luar kampus, dan secara langsung megajarkan kepada mahasiswa cara identifikasi masalahmasalah sosial kerakyatan. PKM secara langsung akan menunjukan keterkaitan langsung antara dunia pendidikan dan upaya perwujudan kesejahteraan masyarakat.

Beberapa aspek yang diperhatikan dalam pelaksanaan kuliah kerja nyata adalah yang pertama keterpaduan pelaksanaan Tri Darma Perguruan Tinggi yang berupa pengajaran, penelitan, dan pengabdian pada masyarakat. Yang kedua adalah pendekatan interdisipliner dan komprehensif yang artinya PKM bertolak dari permasalahan nyata masyarakat yang didekati menggunakan segala ilmu pengetahuan, teknologi dan seni yang susah, sedang, dan atau akan dipelajari. Yang ketiga adalah lintas sektoral yakni melibatkan masyarakat dari berbagai golongan, yang keempat dimensi dan luas dan pragmatis, yang kelima adalah ketelibatan masyarakat secara aktif, yang 
keenam adalah keberlanjutan dan pengembangan, dan yang ketujuh adalah bertumpu pada sumber daya lokal.

PKM tematik COVID-19 adalah Program Pengabdian guna membentuk kepedulian dalam memberdayakan dan mengedukasi masyarakat untuk mencegah penyebaran Corona Virus Disease 19 (COVID-19) dengan tetap mematuhi protokol kesehatan Covid yaitu menjaga jarak fisik (Physical Distancing) dan memakai masker. Pelaksanaan kegiatan PKM Tematik Covid-19 yaitu di Desa Sumberejo. Desa Sumberejo adalah desa yang terletak di Kecamatan Trucuk, Bojonegoro, Jawa Timur. Pelaksanaan kegiatan PKM Tematik Covid-19 dilaksanakan di Desa Sumberejo karena lokasi PKM merupakan daerah yang dekat dengan rumah mahasiswa. Sesuai arahan dari Lembaga Penelitian dan Pengabdian Masyarakat (LPPM) perguruan tinggi Universitas Nahdlatul Ulama Sunan Giri Bojonegoro bahwa pelaksanaan PKM lebih baik di desa masingmasing untuk mengurangi mobilitas dan penularan COVID-19.

Desa Sumberejo memiliki luas 282,8 Ha. Penduduk Desa Sumberejo sebanyak 1.998 Jiwa. Masyarakat di Desa Sumberejo pada umumnya berprofesi sebagai buruh tani sebanyak 390 jiwa, dan mayoritas penduduk berpendidikan lulus Sekolah Dasar sebanyak 699 jiwa. Sehingga agak sulit untuk mengalami perubahan. Hal ini dapat disebabkan oleh karena rendahnya pertumbuhan ekonomi dan jumlah penduduk yang sangat besar. Disamping itu juga disebabkan oleh kurangnya kesadaran masyarakat terhadap asset dan potensi desa yang ada di Desa Sumberejo.

Tujuan PKM adalah agar Dosen Bersama mahasiswa mampu menghayati dan menanggulangi masalah-masalah yang muncul dimasyarakat yang umumnya kompleks. Kemudahan di dalam penanggulangan tersebut dilakukan secara pragmatis dan interdisipliner dan tercermin dalam kegiatan-kegiatan mahasiswa pada saat melaksanakan program-program PKM didesa.

\section{METODE}

PKM di Desa Sumberejo Menggunakan pendekatan Community Based Research, dengan melakukan proses pendampingan masyarakat yaitu dengan menggunakan metode Asset Based Community Development (ABCD). Secara umum, pengertian $\mathrm{ABCD}$ adalah pendekatan pengembangan masyarakat yang didasarkan pada 
asset lokal yang terdapat di suatu wilayah. ${ }^{1}$ Asset tersebut dikembangkan sehingga dapat memecahkan masalah-masalah yang terdapat di wilayah dimana proses pemberdayaan dilaksanakan. $^{2}$

Pendampingan Asset Based Community Development (ABCD) mengutamakan pemanfaatan asset dan potensi yang ada disekitar dan dimiliki oleh masyarakat. ${ }^{3}$ Masyarakat merupakan asset yang berharga bagi sebuah desa. Keberagaman masyarakat Desa dapat digabungkan dengan melihat keterampilan dan potensi yang ada pada setiap masyarakat. Keterampilan masyarakat dapat dijadikan dalam satu wadah kelompok seperti ibu-ibu PKK dan lain-lain. Dengan adanya suatu wadah kelompok dapat menjadikan sebuah kemajuan bagi masyarakat untuk meningkatkan perekonomian. Pendampingan di Desa Sumberajomemiliki 4 langkah kunci untuk malakukan proses riset diantaranya ${ }^{4}$ :

1. Discovery. Tujuan utama dalam proses ini adalah mengungkap dan mengapresiasi sesuatu untuk memberi semangat kepada orang, pekerjaan, dan komunitasnya. Di Desa Sumberajoterdapat banyak pohon papaya yang belum dikembangkan dan hanya dibuat menjadi bahan sayur. Disana mayoritas bermata pencaharian sebagai pedagang dan petani yang mengasilkan panen yang melimpah.

2. Dream. Tahap ini bertujuan untuk berimajinasi (envision) tentang masyarakat ideal di masa depan. Proses ini memanfaatkan informasi pada tahap sebelumnya untuk berspekulasi mengenai kemungkinan perubahan masa depan di masyarakat. Kepala Desa Sumberajo menginginkan agar masyarakat bisa mengembangkan asset yang ada di Desa.

\footnotetext{
${ }^{1}$ Suardi Suardi, Syahrir Mallongi, and Dahliah Baharuddin, 'Model Pembangunan Pertanian Melalui Penerapan Agropolitan Berbasis Partisipasi Di Kabupaten Pinrang Dengan Pendekatan ABCD (Asset Based Community Development)', PARADOKS: Jurnal Ilmu Ekonomi, 2.4 (2019), 48-61.

${ }^{2}$ Praja Firdaus Nuryananda and Budi Prabowo, 'BRICKONOMIC: PEMBANGUNAN KAPASITAS EKONOMI DESA TEGAREN BERDASAR ASET LOKAL LOKAL', Jurnal Bisnis Indonesia, 11.01 (2020).

${ }^{3}$ Harir Mubarok, 'UIN Malang Mengabdi: Pemberdayaan Masyarakat Desa "Kaki Langit" Taji Kecamatan Jabung Kabupaten Malang', KKM UIN Mengabdi Periode II Tahun 2019, 2019.

${ }^{4}$ Andi Ariyadin Putra, 'Identifikasi Aset Sarana Sanitasi Dasar Dengan Pendekatan Asset Based Community

Development (ABCD) Di Desa Baruga Kecamatan Bontomanai Kabupatan Kepulauan Selayar' (Universitas Islam Negeri Alauddin Makassar, 2017).
} 
3. Design. Tujuan proses ini adalah merumuskan strategi proses dan system mengembangkan kolaborasi yang mendukung terwujudnya perubahan kearah positif sesuai dengan mimpi yang telah dirumuskan. Aktivitas utama proses ini adalah menciptakan kolaborasi dan jejaring dalam mencapai mimpi. Dengan adanya asset Desa yang ingin dikembangkan maka dilaksanakan penyuluhan dan pelatihan pengembangan asset desa.

4. Destiny. Tahap ini adalah mengimplementasikan hal-hal yang telah dirumuskan pada tahap design. Tahap ini akan dilakukan secara terus menerus untuk perubahan, perkembangan dan pemanfaatan dialog-dialog, pembelajaran dan inovasi. Dengan telah dilaksanakannya kegiatan penyuluhan dan pelatihan pengembangan buah pepaya dihapkan bisa dikembangkan terus menerus oleh masyarakat cangaan hingga menjadikan desa tersebut lebih maju.

Berdasarkan uraian dari kondisi yang diharapkan, maka diperoleh beberapa kegiatan yang dapat dilaksanakan. kegiatan tersebut adalah:

1. Mengadakan sosialisasi kepada masyarakat desa sumberajo dari kalangan ibu-ibu dan pemuda desa tersebut.

2. Menyelenggarakan acara pelatihan "Sinau Bareng" dengan memanfaatkan keahliah merajut yang kurang maksimal Desa Sumberajo dengan mendatangkan narasumber ahli rajut dari kota Bojonegoro.

3. Pendampingan pemasaran hasil rajut masyasarakat yaitu di media sosial dan marketplace.

4. Memasarkan dan mengenalkan produk rajut Desa Sumberajo yang dilaksanakan setelah adanya pendampingan Pengembangan.

\section{HASIL DAN PEMBAHASAN}

Pelaksanaan kegiatan pengabdian kepada masyaraat "Pemberdayaan Ekonomi Masyarakat Melalui Kerajinan Rajut Desa Sumberejo Kecamatan Trucuk Kabupaten Bojonegoro.” yang memfokuskan pada kelompok rajut benang pada desa tersebut. Beberapa program yang telah terlaksana diantaranya sosialisasi dan pelatihan pelatihan dan desain rajut berupa tas, gelang, penjepit rambut, konektor masker, dompet. Program yang masih berlangsung saat ini adalah pendampingan kelompok dalam hal memperbaiki kualitas produk dan peningkatan kemampuan kelompok rajut dalam 
meningkatkan hasil produksi rajut. Selain itu juga saat ini masih dilakukan pendampingan kelompok tentang teknik pemasaran produk-produk hasil produksi mereka.

\section{Pelaksanaan kegiatan}

1. Pelatihan marajut

Team PKM sebelum malaksanankan kegiatan ini melakukan pendataan terhadap masyarakat yang minat (Peserta) akan menjadi peserta pelatihan. Kemudian masyarakat yang beminat dikumpulkan untuk diberikan sosialisasi program yang akan mereka jalani. Pada tahap ini, peserta akan diberikan pelatihan langsung

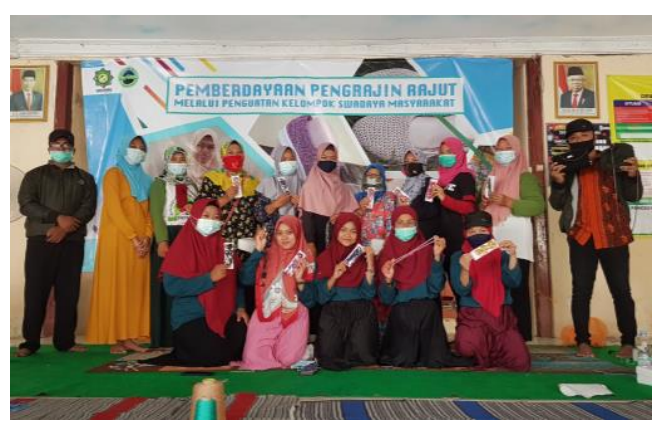
oleh Firdausi Nuzula tentang bagaimana membuat rajutan yang dapat bernilai jual. Pelaksanaan pelatihan keterampilan merajut dimulai dengan pemberian pengetahuan dasar tentang rajutan yang meliputi:

a. Pengenalan alat dan bahan untuk merajut: benang, hakpen, jarum, aksesoris, gunting, lem, kain lapis, dan lain-lain.

b. Simbol dan arti istilah

c. Jenis-jenis tusukan dasar rajutan

d. Jenis-jenis modifikasi tusukan

e. Tehnik merajut

f. Praktik merajut

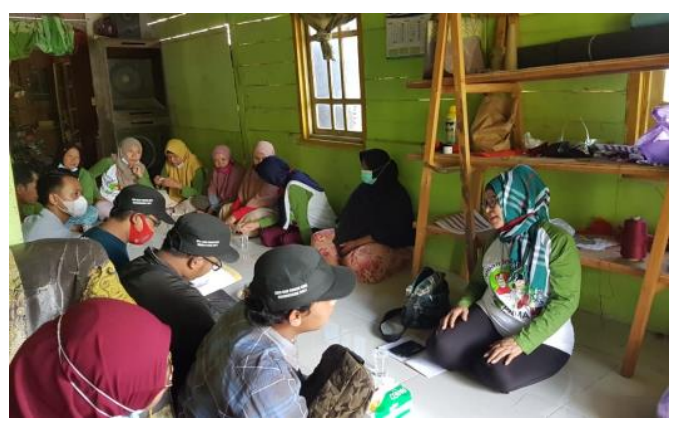

Gambar 1; Pelatihan merajut oleh Firdausi Nuzula pada kegiatan PKM 


\section{Tahap pendampingan}

kegiatan PKM Setelah para peserta mengenal dan melakukan praktik langsung merajut, mereka akan diarahkan kepada pembuatan seni rajutan yang berorientasi pada usaha. Fokus hasil rajutan adalah produk-produk yang banyak dibutuhkan orang dimana para calon pelanggan dapat memilikinya lebih dari satu (banyak pieces) dengan variasi bentuk yang berbeda-beda atau dapat juga menjadikannya sebagai koleksi. Produk-produk tersebut dapat berupa bros jilbab/aksesoris dengan berbagai motif (motif bunga, bando, pita, dll), topi, dan Konektor masker. Selama proses kegiatan, muncul beberapa tambahan jenis produk seperti dompet handphone dan taplak meja. Kegiatan ini diharapkan akan berdampak positif bagi mitra dimana nantinya antar sesama peserta dapat saling berbagi pengetahuan terkait pola-pola rajutan yang telah dipelajari.

3. Tahap pendampingan dan pembinaan

melalui manajemen usaha Dalam hal manajemen usaha, tim pelaksana memberikan pendampingan dan pembinaan kepada kedua mitra. Kegiatan ini diawali dengan memberikan pendidikan (pengetahuan) tentang manajemen usaha yang meliputi:

a. Wawasan kewirausahaan

b. Analisa pasar (studi kelayakan)

c. Pembentukan jaringan kemitraan UKM (Usaha Kecil dan Menengah)

d. Pengelolaan usaha
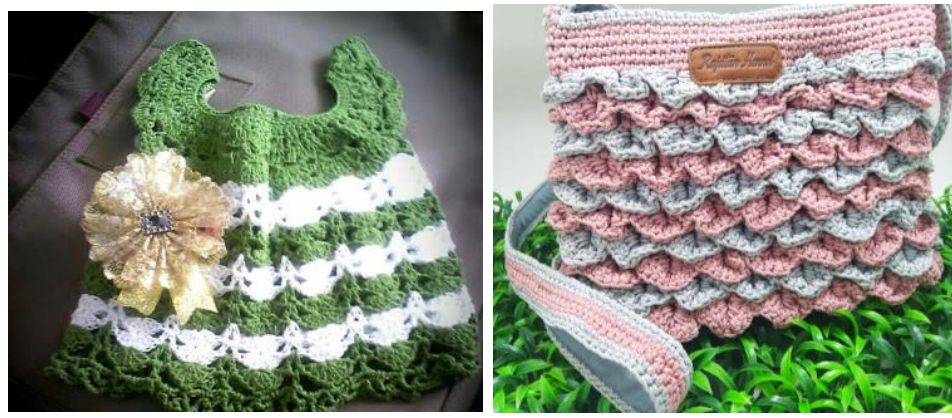

Gambar 2; hasil rajut dari kelompok rajut desa sumberejo

\section{Evaluasi kegiatan}

Alur yang dilakukan pada program pengabdian masyarakat dimulai dari tahap persiapan yang terdiri dari tahap (1) persiapan administrasi sesuai dengan kebutuhan 
sosialisasi dan pelatihan, (2) melakukan koordinasi dengan pihak terkait seperti Kepala Desa, Perangkat dan beberapa pihak lain, (3) membuat konsep sosialisasi dan pelatihan, (4) menyiapkan narasumber yang memiliki kompetensi dibidang rajut dan pemasaran.

Tahap selanjutnya adlaah tahap pelaksanaan sosialisasi dan pelatihan, yang dimualai dengan pemberian pemahaman tentang asset desa sekitar yang dapat dimanfaatkan untuk dijadikan kerajinan rajut yang terdapat keahlian masyarakat tentang rajut yang selama ini kurang maksimal untuk dikembangkan. Selanjutnya pemberian wawasan tentang kerajinan rajut yang memiliki daya jual dan cara memasarkan produk.

Tahap terakhir adalah tahap evaluasi yang dilakukan dengan memberikan presentasi kesimpulan sosialisasi dan pelatihan, praktek langsung serta pembentukan kelompok usaha produk rajut. Selain itu juga peneliti melakukan kerjasama dengan beberapa pihak terkait terutama beberapa marketplace dengan harapan dapat membantu kemandirian masyarakat pedesaan Desa sumberejo untuk lebih produktif dalam memasarkan produk rajut serta dapat membantu peningkatan perekonomian warga.

\section{SIMPULAN}

Kegiatan PKM Tematik 2021 Universitas Nahdlatul Ulama Sunan Giri Bojonegoro di Desa Sumberejo Kecamatan Trucuk dapat terlaksana dengan baik. Kegiatan dapat diterima oleh masyarakat dan mendapat dukungan oleh seluruh jajaran perangkat desa dan beberapa elemen yang senantiasa antusias dengan kegiatan yang berjalan.

Program kerja yang difokuskan pada pengembangan ekonomi masyarakat di masa pandemi. Kegiatan tersebut berupa pengembangan ketrampilan merajut benang Pendampingan pemasaran hasil rajut masyasarakat yaitu di media sosial dan marketplace. Memasarkan dan mengenalkan produk rajut Desa Sumberajo yang dilaksanakan setelah adanya pendampingan Pengembangan 
Program kerja yang terlaksana diantaranya Pendampingan siswa sekolah SD melalui pelaksanaan kegiatan Bimbingan Belajar/Les, Pendampingan santriwan dan santriwati TPQ Baiturrahim, Bimbingan tilawah santriwan santriwati madin Baiturrahim, Peringatan isra' mi'raj Nabi Muhammad SAW, Lomba keagamaan (mewarnai, menggambar, wudhu, adzan dan hafalan juz amma), Pelatihan rajut, Seminar digital marketing, Penyaluran bibit tanaman holtikultura, Pelatian desain grafis, Kerjabakti serta penyemprotan disinfektan, dan Keikutsertaan dalam posyandu Desa Sumberejo serta pembagian pamflet patuh protokol kesehatan. 


\section{DAFTAR PUSTAKA}

Azis, Abdul. 2020. Minda Guru Indonesia: Pandemi Corona, Disrupsi Pendidikan,

Dan Kreativitas Guru. Aceh: Syiah Kuala University Press.

Agunggunanto, Edy Yusuf, Fitrie Arianti, Edi Wibowo Kushartono, and Darwanto Darwanto,

'Pengembangan Desa Mandiri Melalui Pengelolaan Badan Usaha Milik Desa (BUMDes)', Jurnal Dinamika Ekonomi \& Bisnis, 13 (2016)

Djamil, 'Wawancara Bersama (Kepala Desa Cangaan)' (10 Januari 2020)

Kementerian Pendidikan dan Kebudayaan. 2020. Guru Tangguh Di Tengah Pandemi. Jakarta: Wahana Visi Indonesia.

Badan Pusat Statistik, Indeks Pembangunan Desa 2018 (Jakarta: Badan Pusat Statistik, 316AD)

<https://www.bps.go.id/publication/download.html?nrbvfeve=NGVkYWU0YmQ $2 \mathrm{YzE}$

4ZDI0YjFiNDI3M2Z1\&xzmn=aHR0cHM6Ly93d3cuYnBzLmdvLmlkL3B1Ymx pY2F0

aW9uLzIwMTkvMDUvMDkvNGVkYWU0YmQ2YzE4ZDI0YjFiNDI3M2ZIL21 uZGV

rcy1wZW1iYW5ndW5hbi1kZXNhLTIwMTguaHRtbA\%3D\%3D\&twoadfnoarfe auf>

Mubarok, Harir, 'UIN Malang Mengabdi: Pemberdayaan Masyarakat Desa "Kaki Langit"

Taji Kecamatan Jabung Kabupaten Malang', KKM UIN Mengabdi Periode II Tahun 2019, 2019

Nomor, Undang-Undang, 'Tahun 2014 Tentang Desa', 6AD

Nuryananda, Praja Firdaus, and Budi Prabowo, 'BRICKONOMIC: PEMBANGUNAN

KAPASITAS EKONOMI DESA TEGAREN BERDASAR ASET LOKAL LOKAL',

Jurnal Bisnis Indonesia, 11 (2020)

Purbathin Hadi, Agus, '32 Konsep Pemberdayaan, Partisipasi Dan Kelembagaan Dalam Pembangunan', Pusat Pengembangan Masyarakat Agrikarya, 2015

Putra, Andi Ariyadin, 'Identifikasi Aset Sarana Sanitasi Dasar Dengan Pendekatan Asset Based Community Development (ABCD) Di Desa Baruga Kecamatan Bontomanai

Kabupatan Kepulauan Selayar' (Universitas Islam Negeri Alauddin Makassar, 2017).

Pemerintah Kabupaten Bojonegoro. 2021. Data Pemantauan COVID-19 Kabupaten Bojonegoro. https://lawancorona.bojonegorokab.go.id. diakses pada tanggal 31 
Maret 2021.

Pemerintah Provinsi Jawa Timur. 2021. Jatim Tanggap COVID-19. http://infocovid19.jatimprov.go.id. diakses pada tanggal 04 April 2021.

Sidik, Fajar, 'Menggali Potensi Lokal Mewujudkan Kemandirian Desa', JKAP (Jurnal

Kebijakan Dan Administrasi Publik), 2015 <https://doi.org/10.22146/jkap.7962>

Soleh, Ahmad, 'Strategi Pengembangan Potensi Desa', Jurnal Sungkai, 5 (2017), 3552

Suardi, Suardi, Syahrir Mallongi, and Dahliah Baharuddin, 'Model Pembangunan Pertanian Melalui Penerapan Agropolitan Berbasis Partisipasi Di Kabupaten Pinrang Dengan

Pendekatan ABCD (Asset Based Community Development)', PARADOKS: Jurnal Ilmu Ekonomi, 2 (2019), 48-61

Sukarno, Zulfikry, 'Menata Masyarakat Prasejahtera Dalam Penguatan Ekonomi Di Kota Makassar', 2019

Syahid, Nur, 'Wawancara Bersama Kepala Dusun' (10 Januari 2020)

Syahza, Almasdi, 'Rancangan Model Pemberdayaan Ekonomi Masyarakat Pedesaan Berbasis Agribisnis Di Daerah Riau Modeling Of Economic Empowerment Of Rural Community Based On Agro-Business Activities In Riau', Pembangunan Pedesaan, 3 (2003) 